\title{
Bradyrhizobium huanghuaihaiense sp. nov., an effective symbiotic bacterium isolated from soybean (Glycine max L.) nodules
}

\author{
Correspondence \\ Wen Feng Chen \\ chenwf@cau.edu.cn or \\ cauchenwenfeng@gmail.com
}

\author{
Yan Ming Zhang, ${ }^{1}$ Ying Jr Li, ${ }^{1}$ Wen Feng Chen, ${ }^{1}$ En Tao Wang, ${ }^{1,2}$ \\ Xin Hua Sui, ${ }^{1}$ Oin Oin Li, ${ }^{1}$ Yun Zeng Zhang, ${ }^{1}$ Yu Guang Zhou ${ }^{3}$ \\ and Wen Xin Chen ${ }^{1}$
}

\author{
${ }^{1}$ State Key Laboratory of Agrobiotechnology and Department of Microbiology and Immunology, \\ College of Biological Sciences, China Agricultural University, Beijing 100193, PR China \\ ${ }^{2}$ Departamento de Microbiología, Escuela Nacional de Ciencias Biológicas, \\ Instituto Politécnico Nacional, 11340 México Distrito Federal, Mexico \\ ${ }^{3}$ Institute of Microbiology, Chinese Academy of Sciences, Beijing 100101, PR China
}

In a survey of the biodiversity and biogeography of rhizobia associated with soybean (Glycine max L.) in different sites of the Northern (Huang-Huai-Hai) Plain of China, ten strains were defined as representing a novel genomic species in the genus of Bradyrhizobium. They were distinguished from defined species in restriction fragment length polymorphism (RFLP) analysis of the 16S rRNA gene and the 16S-23S rRNA gene intergenic spacer (IGS). In BOX-PCR, these strains presented two patterns that shared $94 \%$ similarity, demonstrating that they were a homogenous group with limited diversity. In phylogenetic analyses of the 16S rRNA gene, IGS and housekeeping gene sequences, four representative strains formed a distant lineage within the genus Bradyrhizobium, which was consistent with the results of DNA-DNA hybridization. The strains of this novel group formed effective nodules with G. max, Glycine soja and Vigna unguiculata in cross-nodulation tests and harboured symbiotic genes (nodC and nifH) identical to those of reference strains of Bradyrhizobium japonicum, Bradyrhizobium liaoningense and 'Bradyrhizobium daqingense' originating from soybean, implying that the novel group may have obtained these symbiotic genes by lateral gene transfer. In analyses of cellular fatty acids and phenotypic features, some differences were found between the novel group and related Bradyrhizobium species, demonstrating that the novel group is distinct phenotypically from other Bradyrhizobium species. Based upon the data obtained, these strains are proposed to represent a novel species, Bradyrhizobium huanghuaihaiense sp. nov., with CCBAU $23303^{\top}$ (=LMG $26136^{\top}=$ CGMCC $1.10948^{\top}=$ HAMBI $\left.3180^{\top}\right)$ as the type strain. The DNA G $+\mathrm{C}$ content of strain CCBAU $23303^{\top}$ is $61.5 \mathrm{~mol} \%\left(T_{\mathrm{m}}\right)$.
Soybean (Glycine max L.) is an important crop worldwide for oil and protein production. It forms nitrogen-fixing root nodules with diverse symbiotic bacteria, including five Bradyrhizobium species (Bradyrhizobium japonicum, B. elkanii, B. liaoningense, B. yuanmingense and ' $B$. daqingense')

\footnotetext{
Abbreviations: IGS, intergenic spacer; ML, maximum-likelihood; MLSA, multilocus sequence analysis; $\mathrm{NJ}$, neighbour-joining; RFLP, restriction fragment length polymorphism.

The GenBank/EMBL/DDBJ accession numbers for the $16 \mathrm{~S}$ rRNA gene, IGS, recA, gInll, atpD, nodC and nifH sequences of strain CCBAU 23303 ${ }^{\top}$ are HQ231463, HQ428043, HQ.231595, HQ231639, HO.231682, HQ.231507 and HQ231551, respectively.
}

Four supplementary figures and two supplementary tables are available with the online version of this paper.
(Ando \& Yokoyama, 1999; Appunu et al., 2008; Han et al., 2009; Kuykendall et al., 1992; Li et al., 2011a; Man et al., 2008; Wang et al., 2012) and two Ensifer species, Ensifer fredii and E. sojae (Chen et al., 1988; Han et al., 2009; Li et al., $2011 \mathrm{a}, \mathrm{b})$. Note that the name 'Bradyrhizobium daqingense' has not yet been effectively or validly published (Wang et al., 2012). In addition to species associated with soybean, other Bradyrhizobium species isolated from different sources have been described, including Bradyrhizobium betae from roots of sugar beet (Rivas et al., 2004), Bradyrhizobium canariense from root nodules of genistoid legumes (Vinuesa et al., 2005a), Bradyrhizobium denitrificans from soil (van Berkum et al., 2006), Bradyrhizobium iriomotense from tumour-like roots of the legume Entada koshunensis (Islam et al., 2008), Bradyrhizobium pachyrhizi and Bradyrhizobium jicamae 
from nodules of Pachyrhizus erosus (Ramírez-Bahena et al., 2009), Bradyrhizobium lablabi from root nodules of Lablab purpureus (Chang et al., 2011) and Bradyrhizobium cytisi from nodules of Cytisus villosus (Chahboune et al., 2011).

During an investigation of the biodiversity and biogeography of rhizobia associated with soybean grown in the Northern (Huang-Huai-Hai) Plain of China, ten bacterial strains were defined as 'Bradyrhizobium sp. I' by PCRbased restriction fragment length polymorphism (RFLP) analysis of the 16S rRNA gene and 16S-23S rRNA gene intergenic spacer (IGS). Sequencing of the $16 \mathrm{~S}$ rRNA, recA, $g \operatorname{lnII}$ and $\operatorname{atpD}$ genes of a representative strain CCBAU 051161, confirmed the distinct phylogeny of the group in the genus Bradyrhizobium (Zhang et al., 2011). To clarify the taxonomic position of these ten strains, further analyses were performed in the present study.

The ten Bradyrhizobium sp. I strains, CCBAU 051145, CCBAU 051158, CCBAU 051161, CCBAU $23303^{\mathrm{T}}$, CCBAU 23304, CCBAU 23328, CCBAU 23332, CCBAU 25541, CCBAU 45502 and CCBAU 45504, were obtained from seven sites in four Chinese provinces (Hebei, Anhui, Shandong and Henan) (Zhang et al., 2011). In the present study, the bacteria were maintained on YMA slants at $4{ }^{\circ} \mathrm{C}$ for short-term storage and in $20 \%(\mathrm{w} / \mathrm{v})$ glycerol at $-80{ }^{\circ} \mathrm{C}$ for long-term storage. They were normally incubated at $28{ }^{\circ} \mathrm{C}$.

To evaluate the genetic diversity among the ten strains, BOX-PCR fingerprinting was performed as described previously (Nick et al., 1999). The primer BOXAIR (5'CTACGGCAAGGCGACGCTGACG-3') and the procedure of Versalovic et al. (1994) were used to amplify the fragments with genomic DNA as template, which was extracted from each strain with the GUTC method (Terefework et al., 2001). The PCR products were subjected to electrophoresis in $1.5 \%(\mathrm{w} / \mathrm{v})$ agarose gels supplemented with $0.5 \mu \mathrm{g}$ ethidium bromide $\mathrm{ml}^{-1}$. RFLP patterns were photographed, normalized, combined and clustered using the GelCompar II software package (Applied Maths) (Vauterin \& Vauterin, 1992). In this analysis, two BOX-PCR patterns were distinguished from nine of the ten strains; no PCR product was obtained from strain CCBAU 23332. Strains CCBAU $23303^{\mathrm{T}}$ and CCBAU 23304 had the same pattern, which shared $94 \%$ similarity with the pattern displayed by the other seven strains (Fig. S1, available in IJSEM Online), demonstrating that these nine strains comprised at least two clones and that these strains represented a genomic species with little diversity, although they were isolated from different geographical regions.

Based upon their high genetic relatedness, four strains (CCBAU 051161, CCBAU 25541, CCBAU 23303 ${ }^{\mathrm{T}}$ and CCBAU 45502) representing the two BOX-PCR patterns and originating from the four provinces were subjected to further analyses.

For phylogenetic analyses, genomic DNA extracted as mentioned above from each strain was used as a template to amplify the following targets: (i) the $16 \mathrm{~S}$ rRNA gene $(\sim 1500 \mathrm{nt})$ with primers P1 and P6 (Tan et al., 1997) and the PCR protocol of Weisburg et al. (1991); (ii) the 16S23S rRNA gene IGS $(\sim 1200 \mathrm{nt})$ using the primer pair FGPS6/23S-38 (Normand et al., 1992) and the PCR protocol of Rasolomampianina et al. (2005); (iii) partial sequences of the housekeeping genes $r e c A(\sim 600 \mathrm{nt}), g \ln I$ $(\sim 680 \mathrm{nt})$ and $\operatorname{atpD}(\sim 530 \mathrm{nt})$ using primer pairs recA41F/ recA640R, glnII12F/glnII689R and atpD255F/atpD782R, respectively, and protocols described by Vinuesa et al. (2005b); (iv) nodC ( $700 \mathrm{bp}$ ) with primer pair nodCF540/ nodCR1160 and the protocol of Sarita et al. (2005); and (v) nifH ( $\sim 800 \mathrm{bp})$ with the primer pair nifHF/nifHR and the protocol of Laguerre et al. (2001).

All PCR products were sequenced directly as described previously (Hurek et al., 1997). The sequences acquired in this study and those of related Bradyrhizobium strains obtained from GenBank by BLAST searching were aligned using CLUSTAL $\mathrm{w}$ in the MEGA 4 software (Tamura et al., 2007). Aligned sequences were analysed by using the MEGA 4.0 software to produce a Kimura two-parameter distance matrix (Kimura, 1980) and to reconstruct an optimal rooted tree using the neighbour-joining (NJ) method (Saitou \& Nei, 1987) with bootstrap analysis using 1000 replications. Maximum-likelihood (ML) trees were also reconstructed with the PhyML 3.0 program (Guindon \& Gascuel, 2003). The nucleotide substitution model produced by the Akaike information criterion was implemented in Modeltest 3.7 (Posada \& Crandall, 1998) and PAUP 4.0b (Swofford, 2000).

The four representative strains had identical 16S rRNA gene sequences and they were most related to $B$. iriomotense LMG $24129^{\mathrm{T}}(99.7 \%$ similarity) in the NJ tree (Fig. 1). The sequences of the type strains of $B$. liaoningense, $B$. betae, $B$. japonicum and $B$. canariense and the proposed type strain of ' $B$. daqingense' presented similarities of 99.2, 99.2, 99.1, 99.1 and $99.1 \%$, respectively, with CCBAU $23303^{\mathrm{T}}$. Strain CCBAU $23303^{\mathrm{T}}$ shared $16 \mathrm{~S}$ rRNA gene sequence similarities of 97.2, 97.8, 98.2, 98.7, 98.8, 99.2 and 99.3\%, respectively, with Afipia felis B-91-007352 ${ }^{\mathrm{T}}$, Rhodopseudomonas palustris ATCC $17001^{\mathrm{T}}$, Nitrobacter winogradskyi ATCC 14123, Agromonas oligotrophica JCM $1494^{\mathrm{T}}$, B. denitrificans LMG $8443^{\mathrm{T}}$, 'Bradyrhizobium lupini' KM50-90 and 'B. lupini' FN 13. The high degree of sequence similarity supports the conclusion that these species could be classified as members of a single genus (Willems \& Collins, 1992). Similar results were obtained when the sequences were analysed using the ML method (not shown).

In sequence analysis of the 16S-23S rRNA gene IGS, the topologies of the NJ and ML phylogenetic trees (not shown) were the same, and the four representative strains showed little variation. Strains CCBAU $23303^{\mathrm{T}}$, CCBAU 25541 and CCBAU 45502 had identical IGS sequences, which were $99.8 \%$ similar to that of CCBAU 051161. Strain CCBAU $23303^{\mathrm{T}}$ had IGS sequence similarities of $95.3 \%$ with $B$. yuanmingense CCBAU $10071^{\mathrm{T}}$ and 95.1, 94.8, 93.7, 93.7, 


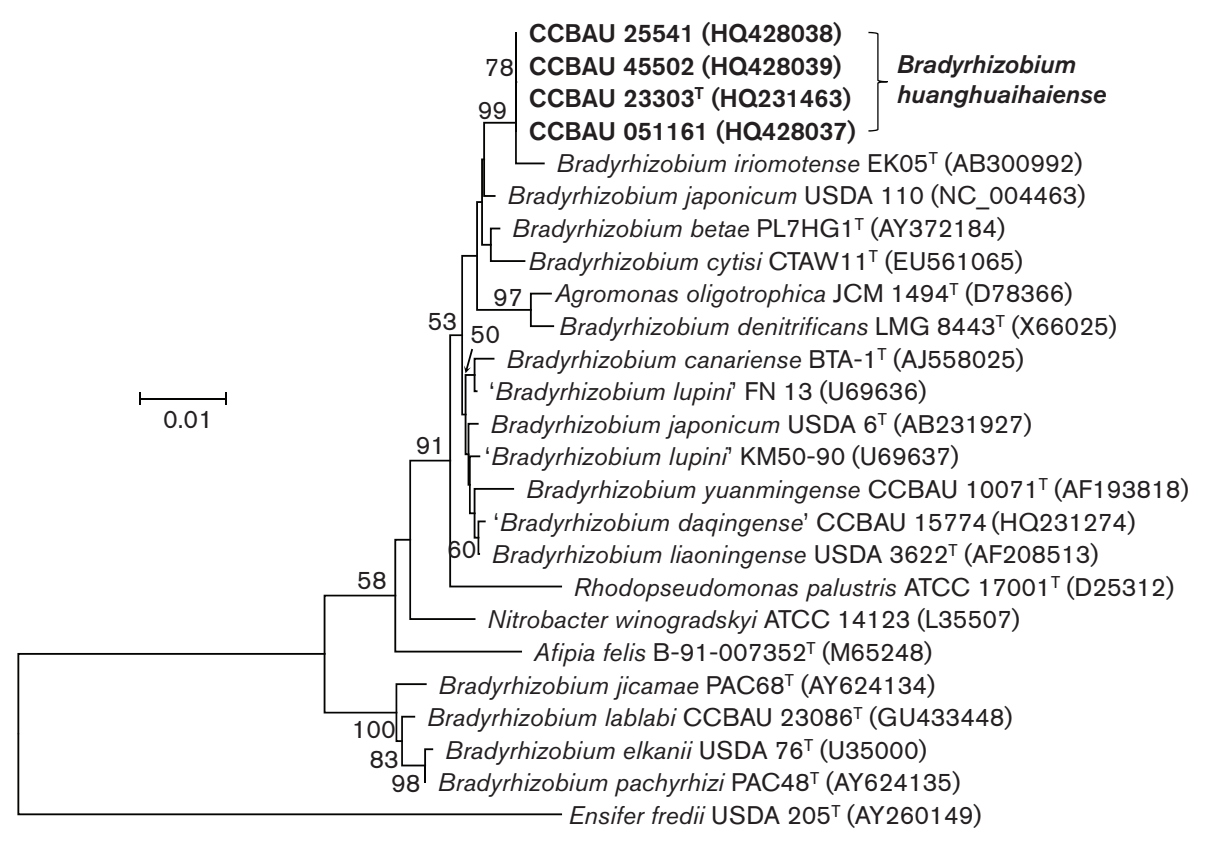

Fig. 1. Phylogenetic tree based on $16 \mathrm{~S}$ rRNA gene sequences (1229 nt) showing the phylogenetic relationships of representative strains of Bradyrhizobium huanghuaihaiense sp. nov. with other Bradyrhizobium species. Ensifer fredii USDA $205^{\top}$ was used as an outgroup. The NJ tree was derived from a distance matrix (Kimura's two-parameter model). Bootstrap confidence levels $\geqslant 50 \%$ (calculated for 1000 subsets) are indicated at internodes. Bar, $1 \%$ nucleotide substitution.

92.0 and $91.8 \%$, respectively, with B. japonicum USDA $6^{\mathrm{T}}$, ' $B$. daqingense' CCBAU 15774, B. betae LMG $21987^{\mathrm{T}}, B$. canariense BTA- $1^{\mathrm{T}}, B$. iriomotense LMG $24129^{\mathrm{T}}$ and $B$. liaoningense USDA $3622^{\mathrm{T}}$. Strains of the remaining Bradyrhizobium species presented similarities of less than $90 \%$ with CCBAU $23303^{\mathrm{T}}$ (Table S1). These data demonstrated that the four strains represented a novel species, according to the conclusion of Willems et al. (2003) that two bradyrhizobial strains that share less than $95.5 \%$ IGS sequence similarity belong to different genomic species.

The four representative strains showed identical sequences for three housekeeping genes $(r e c A, g l n I I$ and $a t p D)$. For each of the three genes, the phylogenetic relationships were consistent between the NJ and ML trees (not shown). The most similar strains to CCBAU $23303^{\mathrm{T}}$ were ' $B$. daqingense' CCBAU 15774 for the recA gene (94.6\% similarity), $B$. japonicum USDA $6^{\mathrm{T}}$ for the glnII gene $(95.8 \%)$ and B. betae LMG $21987^{\mathrm{T}}$ for the atpD gene $(96.2 \%)$. In the multilocus sequence analysis (MLSA), the ML tree reconstructed with the combined sequences of the three housekeeping genes (Fig. 2) had the same topology as the NJ tree (not shown). The novel strain CCBAU $23303^{\mathrm{T}}$ was most similar to $B$. liaoningense USDA $3622^{\mathrm{T}}$ and B. betae LMG $21987^{\mathrm{T}}$ in MLSA ( $94.7 \%$ similarity) (Table S1), which is different from the results of analyses of the 16S rRNA gene and the IGS. The four representative strains in this study formed a distinctive lineage that differed from all defined species.

Symbiotic (nod and nif) genes are normally located on transferable elements (plasmids or symbiotic islands), so they cannot be used as gene markers for taxonomy. However, they can offer information on symbiotic specificity between rhizobia and legumes, and can reveal the host ranges of rhizobia (Laguerre et al., 2001). In the nodC phylogenetic tree (Fig. S2), the four representative strains showed identical sequences to $B$. japonicum USDA $6^{\mathrm{T}}$ and ' $B$. daqingense' CCBAU 15774, linked to B. yuanmingense CCBAU $10071^{\mathrm{T}}$ at $92 \%$ similarity (Table S1). The nifH phylogenetic tree had the same topological structure as the nodC tree (not shown). These results suggest that the novel Bradyrhizobium strains examined in the present study might have obtained their symbiotic (nod and nif) genes from other soybean-nodulating Bradyrhizobium strains by horizontal gene transfer, as reported for other rhizobia (Moulin et al., 2004).

DNA-DNA hybridization is a standard method for bacterial species definition (Wayne et al., 1987). In the present study, total DNA was extracted using the method of Marmur (1961) from the four representative strains and reference strains. DNA-DNA relatedness between CCBAU $23303^{\mathrm{T}}$ and other strains was estimated using renaturation rate technology (De Ley et al., 1970). The DNA-DNA relatedness of CCBAU $23303^{\mathrm{T}}$ with CCBAU 051161, CCBAU 25541 and CCBAU 45502 was $88.2,90.3$ and $91.7 \%$, respectively, demonstrating that they are members of the same genomic species. The DNA-DNA relatedness between CCBAU $23303^{\mathrm{T}}$ and reference strains $B$. liaoningense USDA $3622^{\mathrm{T}}$, B. betae LMG $21987^{\mathrm{T}}, B$. japonicum USDA $6^{\mathrm{T}}, B$. canariense BTA-1 ${ }^{\mathrm{T}}$, ' $B$. daqingense' CCBAU 15774 and $B$. yuanmingense CCBAU 


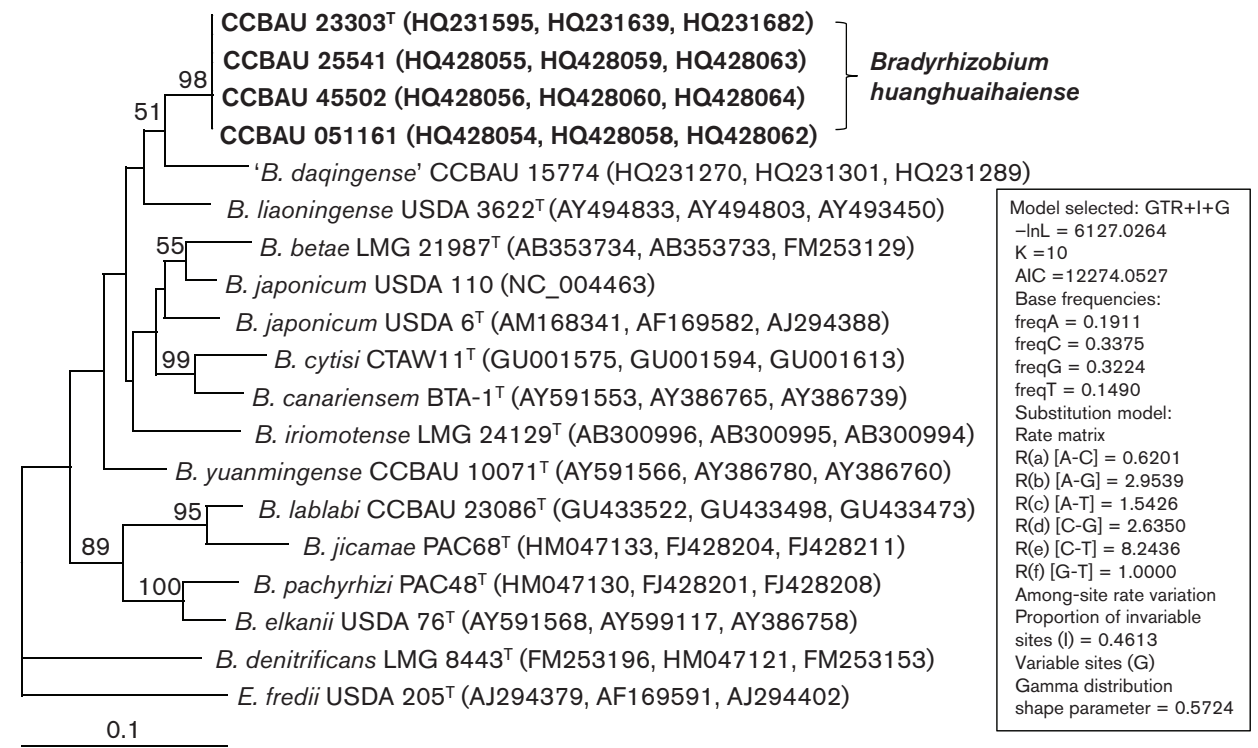

Fig. 2. $M L$ tree reconstructed based on concatenated sequences of $r e c A(381 \mathrm{nt}), g \ln / l(513 \mathrm{nt})$ and atpD (423 nt) showing the phylogenetic relationships of representative strains of $B$. huanghuaihaiense sp. nov. under the best-fit model shown. Ensifer fredii USDA $205^{\top}$ was used as an outgroup. ML bootstrap support values for 100 pseudoreplicates of the dataset are provided at the corresponding nodes. Bar, $10 \%$ nucleotide substitution.

$10071^{\mathrm{T}}$ was $50.0,44.5,46.8,44.5,37.1$ and $36.1 \%$, respectively (detailed data available in Table S1), which are much lower than the threshold value of $70 \%$ DNA-DNA relatedness recommended for species definition (Wayne et al., 1987).

The DNA G $+\mathrm{C}$ content was determined by the thermal denaturation method (Mandel \& Marmur, 1968) using DNA from Escherichia coli $\mathrm{K}-12$ as a standard. The DNA $\mathrm{G}+\mathrm{C}$ content of the four representative strains ranged from 60.8 to $62.4 \mathrm{~mol} \%\left(T_{\mathrm{m}}\right)$, which is within the range for recognized members of the genus Bradyrhizobium.

Cellular fatty acids of strain CCBAU $23303^{\mathrm{T}}$ were assayed together with those of B. liaoningense USDA $3622^{\mathrm{T}}$, B. betae LMG $21987^{\mathrm{T}}, B$. japonicum USDA $6^{\mathrm{T}}, B$. canariense BTA$1^{\mathrm{T}}, B$. yuanmingense CCBAU $10071^{\mathrm{T}}$ and ' $B$. daqingense' CCBAU 15774 in order to examine differences between the novel strain and closely related species. The strains were cultured aerobically on YMA medium at $28{ }^{\circ} \mathrm{C}$ and cells were collected during the late-exponential phase of growth. Fatty acid methyl esters were prepared and separated using the method described by Sasser (1990) and identified with the MIDI Sherlock Microbial Identification System (Sherlock license CD version 6.0), using the TSBA6 database. A total of 27 fatty acids were detected in strain CCBAU $23303^{\mathrm{T}}$ (Table S2). All tested strains contained the fatty acids $12: 0,16: 0,16: 1 \omega 5 c, 17: 0,17: 1 \omega 6 c, 17: 1 \omega 8 c$, summed feature $3(16: 1 \omega 6 c$ and/or $16: 1 \omega 7 c)$ and summed feature $8(18: 1 \omega 6 c$ and/or $18: 1 \omega 7 c)$, but the percentages of these fatty acids varied (Table S2). Summed feature 8 and 16:0 were the two most dominant fatty acids in all tested strains, consistent with previous reports for the genus Bradyrhizobium (Tighe et al., 2000).
For polar lipid analysis, cells of strain CCBAU $23303^{\mathrm{T}}$ were grown to late-exponential phase in TY broth (5 g tryptone, 3 g yeast extract and $0.7 \mathrm{~g} \mathrm{CaCl}_{2} \cdot 2 \mathrm{H}_{2} \mathrm{O}, \mathrm{pH} 6.8-7.2$, in 11 deionized water) at $28{ }^{\circ} \mathrm{C}$ with shaking. Polar lipids were extracted from $200-250 \mathrm{mg}$ freeze-dried cells according to Minnikin et al. (1984) and separated by two-dimensional TLC using chloroform/methanol/water $(65: 25: 4$, by vol.) in the first dimension and chloroform/acetic acid/methanol/water $(80: 18: 12: 5$, by vol.) in the second dimension. The following spray reagents were used for detection of phospholipids, aminolipids and glycolipids, respectively: molybdenum blue spray reagent (results recorded immediately), ninhydrin $(0.4 \%, \mathrm{w} / \mathrm{v}$, in 1-butanol saturated with distilled water; developed at $100{ }^{\circ} \mathrm{C}$ for $5 \mathrm{~min}$ ) and anisaldehyde reagent (developed at $110{ }^{\circ} \mathrm{C}$ for $4-6 \mathrm{~min}$ ). Each spot was identified by comparing with standard mixtures of polar lipids (Sigma-Aldrich). The phospholipid profile is shown in Fig. S3. Strain CCBAU $23303^{\mathrm{T}}$ contained phosphatidylcholine and phosphatidylethanolamine as major components (each representing about $40 \%$ of the total phospholipids) and phosphatidylglycerol and cardiolipin as minor components (each representing about $10 \%$ of the total). Phosphatidylethanolamine was the only aminolipid detected. No glycolipid could be detected. The phospholipid components were completely congruent with those of B. japonicum USDA 110 and Bradyrhizobium sp. strain 32H1 (Miller et al., 1990).

Cell morphology of strain CCBAU $23303^{\mathrm{T}}$ (Fig. S4) was investigated with scanning electron microscopy after cultivation on a YMA plate at $28{ }^{\circ} \mathrm{C}$ for 7 days. Phenotypic features of the four representative strains and the type strains 
of related Bradyrhizobium species were determined according to the methods described by Gao et al. (1994). Biochemical tests including catalase and oxidase production, the VogesProskauer reaction and hydrolysis of starch and Tween 80 were performed according to Smibert \& Krieg (1994). Production of hydrogen sulfide from cysteine was determined as described by Barrow \& Feltham (1993). The four representative strains had the same characteristics in most cases except for utilization of L-arginine, L-cystine, D-glutamic acid and L-lysine as sole nitrogen sources (Table 1). The combination of phenotypic features listed in Table 1 could be used to differentiate the novel strains from the type strains of related species.

Cross-nodulation tests were performed in Leonard jars filled with sterilized vermiculite moistened with nitrogen-free solution using the standard procedure of Vincent (1970).

Table 1. Distinctive features of representative novel strains ( $B$. huanghuaihaiense sp. nov.) and their closest relatives

Strains: 1, CCBAU 051161; 2, CCBAU 25541; 3, CCBAU $23303^{\mathrm{T}} ; 4$, CCBAU 45502; 5, B. liaoningense USDA $3622^{\mathrm{T}} ; 6$, B. yuanmingense CCBAU $10071^{\mathrm{T}} ; 7$, B. japonicum USDA $6^{\mathrm{T}} ; 8$, B. betae $\mathrm{LMG} 21987^{\mathrm{T}} ; 9$, B. canariense $\mathrm{BTA}-1^{\mathrm{T}}$. Data were obtained in this study. + , Growth; - , no growth; w, weakly positive.

\begin{tabular}{|c|c|c|c|c|c|c|c|c|c|}
\hline Characteristic & 1 & 2 & 3 & 4 & 5 & 6 & 7 & 8 & 9 \\
\hline \multicolumn{10}{|c|}{$\begin{array}{l}\text { Utilization of sole carbon } \\
\text { sources }\end{array}$} \\
\hline Inulin & + & + & + & + & - & - & + & - & - \\
\hline D-Galactose & + & + & + & + & - & + & + & + & + \\
\hline D-Glucose & + & + & + & + & - & - & + & $-^{*}$ & + \\
\hline Maltose & + & + & + & + & - & - & + & - & - \\
\hline Melibiose & + & + & + & + & + & - & + & - & - \\
\hline L-Rhamnose & + & + & + & + & + & - & $\mathrm{w}$ & - & $-*$ \\
\hline D-Ribose & + & + & + & + & + & - & + & w & + \\
\hline Sodium acetate & + & + & + & + & + & - & + & + & + \\
\hline Sodium D-gluconate & + & + & + & + & + & - & + & + & + \\
\hline Hippuric acid & + & + & + & + & - & + & + & + & + \\
\hline D-Sorbitol & - & - & - & - & - & - & - & - & + \\
\hline Sorbose & + & + & + & + & - & - & + & + & - \\
\hline Sucrose & + & + & + & + & - & + & + & $\mathrm{w}$ & - \\
\hline \multicolumn{10}{|c|}{$\begin{array}{l}\text { Utilization of sole nitrogen } \\
\text { sources }\end{array}$} \\
\hline L-Arginine & - & + & - & - & - & - & + & - & - \\
\hline L-Aspartic acid & + & + & + & + & + & - & + & $\mathrm{w}$ & + \\
\hline L-Cystine & - & + & + & - & $-*$ & - & - & + & + \\
\hline D-Glutamic acid & - & + & + & - & $-*$ & - & - & - & - \\
\hline L-Isoleucine & + & + & + & + & + & - & + & + & + \\
\hline L-Lysine & - & + & $\mathrm{w}$ & - & - & - & + & + & - \\
\hline L-Threonine & + & + & + & + & - & - & + & + & + \\
\hline \multicolumn{10}{|l|}{ Growth on YMA with/at: } \\
\hline $1 \% \mathrm{NaCl}$ & - & - & - & - & - & - & + & + & $+^{*}$ \\
\hline $37^{\circ} \mathrm{C}$ & + & + & + & - & - & + & - & - & + \\
\hline
\end{tabular}

${ }^{*}$ Data obtained in this study that are not consistent with those reported previously.
The representative strain CCBAU $23303^{\mathrm{T}}$ could form effective nodules with Glycine max, Glycine soja and Vigna unguiculata, but not with Lotus corniculatus, Trifolium repens, Medicago sativa, Pisum sativum, Phaseolus vulgaris, Leucaena leucocephala or Melilotus albus.

According to the phenotypic and genetic characteristics determined in our tests and the current criteria for definition of rhizobial species (Young, 1996), we propose that the ten strains in Bradyrhizobium sp. I (Zhang et al., 2011) represent a novel species in the genus Bradyrhizobium, Bradyrhizobium huanghuaihaiense sp. nov.

\section{Description of Bradyrhizobium huanghuaihaiense sp. nov.}

Bradyrhizobium huanghuaihaiense (huang.huai.hai.en'se. N.L. neut. adj. huanghuaihaiense of or belonging to Huang-Huai-Hai Plain, China, referring to the fact that the first strains were isolated from root nodules of soybean grown on the Huang-Huai-Hai Plain).

Cells are Gram-negative, aerobic, non-spore-forming rods, $1.35 \mu \mathrm{m}$ long and $0.46 \mu \mathrm{m}$ wide. Colonies are circular, convex and translucent, $1 \mathrm{~mm}$ in diameter within 7 days at $28{ }^{\circ} \mathrm{C}$ on YMA medium. The generation time is $7-9 \mathrm{~h}$ in TY broth. Grows at $\mathrm{pH} 6-9$, with optimum growth at $\mathrm{pH}$ 7.0. Growth occurs at $10{ }^{\circ} \mathrm{C}$ and between 28 and $37^{\circ} \mathrm{C}$ (optimally at $28{ }^{\circ} \mathrm{C}$ ). Tolerates $60{ }^{\circ} \mathrm{C}$ for $10 \mathrm{~min}$. Cannot grow on YMA in the presence of $1 \% \mathrm{NaCl}$. No growth in Tween 80 or in Luria-Bertani broth. Catalase, oxidase and hydrolysis of starch are positive. Nile blue reduction, phenylalanine dehydrogenase production and Voges-Proskauer reaction are negative. Cannot produce hydrogen sulfide. In addition to the carbon sources listed in Table 1, the type strain can metabolize D-arabinose, D-galactose, melibiose, D-ribose, sodium D-gluconate, hippuric acid, sodium succinate, sorbose, sucrose, calcium gluconate, D-fructose, D-mannose, sodium pyruvate, D-xylose and L-proline as sole carbon sources, but not adipic acid, dulcitol, meso-erythritol, lactose, melezitose, D-sorbitol, raffinose, soluble starch, L-arginine, glycine, DL-asparagine or L-methionine. The type strain cannot grow on D-threonine as a sole nitrogen source. Strains of the novel species are resistant to the antibiotics $\left(\mu \mathrm{g} \mathrm{ml}^{-1}\right)$ ampicillin (50), kanamycin (5), neomycin sulfate (50), streptomycin (5), erythromycin (100), chloramphenicol (50) and gentamicin (100). Summed feature 8 (18:1 $1 \omega 6 c$ and/or $18: 1 \omega 7 c$ ) and $16: 0$ are the dominant fatty acids. The type strain contains phosphatidylcholine, phosphatidylethanolamine, phosphatidylglycerol and cardiolipin.

The type strain, CCBAU $23303^{\mathrm{T}} \quad\left(=\mathrm{LMG} 26136^{\mathrm{T}}\right.$ $=$ CGMCC $1.10948^{\mathrm{T}}=$ HAMBI $3180^{\mathrm{T}}$ ), was isolated from effective nodules of soybean (Glycine max L.). Its DNA $\mathrm{G}+\mathrm{C}$ content is $61.5 \mathrm{~mol} \%\left(T_{\mathrm{m}}\right)$.

\section{Acknowledgements}

Thanks to Yan Li and Xiao Xia Zhang for their help with the determination of polar lipids and fatty acids, respectively. This work 
was financed by the Foundation of the State Key Basic Research and Development Plan of China (grant 2010CB126500), the Funds of Commercialization of Agricultural and Scientific Findings, MOST (2008GB23600460), the National Natural Science Foundation of China (project nos 30970004 and 30870004) and funds from SKLAB (2009SKLAB05-1, 2010SKLAB01-1). E. T. W. is supported financially by grants SIP20100067 and 20110423 authorized by IPN and PICS083 authorized by the ICyT DF of Mexico.

\section{References}

Ando, S. \& Yokoyama, T. (1999). Phylogenetic analyses of Bradyrhizobium strains nodulating soybean (Glycine max) in Thailand with reference to the USDA strains of Bradyrhizobium. Can J Microbiol 45, 639-645.

Appunu, C., N'Zoue, A. \& Laguerre, G. (2008). Genetic diversity of native bradyrhizobia isolated from soybeans (Glycine max L.) in different agricultural-ecological-climatic regions of India. Appl Environ Microbiol 74, 5991-5996.

Barrow, G. I. \& Feltham, R. K. A. (editors) (1993). Cowan and Steel's Manual for the Identification of Medical Bacteria, 3rd edn. Cambridge: Cambridge University Press.

Chahboune, R., Carro, L., Peix, A., Barrijal, S., Velázquez, E. \& Bedmar, E. J. (2011). Bradyrhizobium cytisi sp. nov., isolated from effective nodules of Cytisus villosus. Int J Syst Evol Microbiol 61, 29222927.

Chang, Y. L., Wang, J. Y., Wang, E. T., Liu, H. C., Sui, X. H. \& Chen, W. X. (2011). Bradyrhizobium lablabi sp. nov., isolated from effective nodules of Lablab purpureus and Arachis hypogaea. Int J Syst Evol Microbiol 61, 2496-2502.

Chen, W. X., Yan, G. H. \& Li, J. L. (1988). Numerical taxonomic study of fast-growing soybean rhizobia and a proposal that Rhizobium fredii be assigned to Sinorhizobium gen. nov. Int J Syst Bacteriol 38, 392-397.

De Ley, J., Cattoir, H. \& Reynaerts, A. (1970). The quantitative measurement of DNA hybridization from renaturation rates. Eur $J$ Biochem 12, 133-142.

Gao, J. L., Sun, J. G., Li, Y., Wang, E. T. \& Chen, W. X. (1994). Numerical taxonomy and DNA relatedness of tropical rhizobia isolated from Hainan Province, China. Int J Syst Bacteriol 44, 151158.

Guindon, S. \& Gascuel, O. (2003). A simple, fast, and accurate algorithm to estimate large phylogenies by maximum likelihood. Syst Biol 52, 696-704.

Han, L. L., Wang, E. T., Han, T. X., Liu, J., Sui, X. H., Chen, W. F. \& Chen, W. X. (2009). Unique community structure and biogeography of soybean rhizobia in the saline-alkaline soils of Xinjiang, China. Plant Soil 324, 291-305.

Hurek, T., Wagner, B. \& Reinhold-Hurek, B. (1997). Identification of $\mathrm{N}_{2}$-fixing plant- and fungus-associated Azoarcus species by PCR-based genomic fingerprints. Appl Environ Microbiol 63, 43314339.

Islam, M. S., Kawasaki, H., Muramatsu, Y., Nakagawa, Y. \& Seki, T. (2008). Bradyrhizobium iriomotense sp. nov., isolated from a tumorlike root of the legume Entada koshunensis from Iriomote Island in Japan. Biosci Biotechnol Biochem 72, 1416-1429.

Kimura, M. (1980). A simple method for estimating evolutionary rates of base substitutions through comparative studies of nucleotide sequences. J Mol Evol 16, 111-120.

Kuykendall, L., Saxena, B., Devine, T. \& Udell, S. (1992). Genetic diversity in Bradyrhizobium japonicum Jordan 1982 and a proposal for Bradyrhizobium elkanii sp. nov. Can J Microbiol 38, 501-505.
Laguerre, G., Nour, S. M., Macheret, V., Sanjuan, J., Drouin, P. \& Amarger, N. (2001). Classification of rhizobia based on nodC and nifH gene analysis reveals a close phylogenetic relationship among Phaseolus vulgaris symbionts. Microbiology 147, 981-993.

Li, Q. Q., Wang, E. T., Chang, Y. L., Zhang, Y. Z., Zhang, Y. M., Sui, X. H., Chen, W. F. \& Chen, W. X. (2011a). Ensifer sojae sp. nov., isolated from root nodules of Glycine max grown in saline-alkaline soils. Int J Syst Evol Microbiol 61, 1981-1988.

Li, Q. Q., Wang, E. T., Zhang, Y. Z., Zhang, Y. M., Tian, C. F., Sui, X. H., Chen, W. F. \& Chen, W. X. (2011b). Diversity and biogeography of rhizobia isolated from root nodules of Glycine max grown in Hebei Province, China. Microb Ecol 61, 917-931.

Man, C. X., Wang, H., Chen, W. F., Sui, X. H., Wang, E. T. \& Chen, W. X. (2008). Diverse rhizobia associated with soybean grown in the subtropical and tropical regions of China. Plant Soil 310, 77-87.

Mandel, M. \& Marmur, J. (1968). Use of ultraviolet absorbancetemperature profile for determining the guanine plus cytosine content of DNA. Methods Enzymol 12B, 195-206.

Marmur, J. (1961). A procedure for the isolation of deoxyribonucleic acid from micro-organisms. J Mol Biol 3, 208-218.

Miller, K. J., Shon, B. C., Gore, R. S. \& Hunt, W. P. (1990). The phospholipid composition of Bradyrhizobium spp. Curr Microbiol 21, 205-210.

Minnikin, D. E., O'Donnell, A. G., Goodfellow, M., Alderson, G., Athalye, M., Schaal, A. \& Parlett, J. H. (1984). An integrated procedure for the extraction of bacterial isoprenoid quinones and polar lipids. J Microbiol Methods 2, 233-241.

Moulin, L., Béna, G., Boivin-Masson, C. \& Stepkowski, T. (2004). Phylogenetic analyses of symbiotic nodulation genes support vertical and lateral gene co-transfer within the Bradyrhizobium genus. Mol Phylogenet Evol 30, 720-732.

Nick, G., de Lajudie, P., Eardly, B. D., Suomalainen, S., Paulin, L., Zhang, X., Gillis, M. \& Lindström, K. (1999). Sinorhizobium arboris sp. nov. and Sinorhizobium kostiense sp. nov., isolated from leguminous trees in Sudan and Kenya. Int J Syst Bacteriol 49, 1359-1368.

Normand, P., Cournoyer, B., Simonet, P. \& Nazaret, S. (1992). Analysis of a ribosomal RNA operon in the actinomycete Frankia. Gene 111, 119-124.

Posada, D. \& Crandall, K. A. (1998). ModelTest: testing the model of DNA substitution. Bioinformatics 14, 817-818.

Ramírez-Bahena, M. H., Peix, A., Rivas, R., Camacho, M., RodriguezNavarro, D. N., Mateos, P. F., Martínez-Molina, E., Willems, A. \& Velázquez, E. (2009). Bradyrhizobium pachyrhizi sp. nov. and Bradyrhizobium jicamae sp. nov., isolated from effective nodules of Pachyrhizus erosus. Int J Syst Evol Microbiol 59, 1929-1934.

Rasolomampianina, R., Bailly, X., Fetiarison, R., Rabevohitra, R., Béna, G., Ramaroson, L., Raherimandimby, M., Moulin, L., De Lajudie, P. \& other authors (2005). Nitrogen-fixing nodules from rose wood legume trees (Dalbergia spp.) endemic to Madagascar host seven different genera belonging to alpha- and beta-Proteobacteria. Mol Ecol 14, 4135-4146.

Rivas, R., Willems, A., Palomo, J. L., Garcia-Benavides, P., Mateos, P. F., Martínez-Molina, E., Gillis, M. \& Velázquez, E. (2004). Bradyrhizobium betae sp. nov., isolated from roots of Beta vulgaris affected by tumour-like deformations. Int J Syst Evol Microbiol 54, 1271-1275.

Saitou, N. \& Nei, M. (1987). The neighbor-joining method: a new method for reconstructing phylogenetic trees. Mol Biol Evol 4, 406425.

Sarita, S., Sharma, P. K., Priefer, U. B. \& Prell, J. (2005). Direct amplification of rhizobial nodC sequences from soil total DNA and 
comparison to nodC diversity of root nodule isolates. FEMS Microbiol Ecol 54, 1-11.

Sasser, M. (1990). Identification of bacteria by gas chromatography of cellular fatty acids, MIDI Technical Note 101. Newark, DE: MIDI Inc.

Smibert, R. M. \& Krieg, N. R. (1994). Phenotypic characterization. In Methods for General and Molecular Bacteriology, pp. 607-654. Edited by P. Gerhardt, R. G. E. Murray, W. A. Wood \& N. R. Krieg. Washington, DC: American Society for Microbiology.

Swofford, D. (2000). PAUP*: phylogenetic analysis using parsimony (and other methods), version 4, b10. Sunderland, MA: Sinauer Associates.

Tamura, K., Dudley, J., Nei, M. \& Kumar, S. (2007). MEGA4: molecular evolutionary genetics analysis (MEGA) software version 4.0. Mol Biol Evol 24, 1596-1599.

Tan, Z. Y., Xu, X. D., Wang, E. T., Gao, J. L., Martinez-Romero, E. \& Chen, W. X. (1997). Phylogenetic and genetic relationships of Mesorhizobium tianshanense and related rhizobia. Int J Syst Bacteriol 47, 874-879.

Terefework, Z., Kaijalainen, S. \& Lindström, K. (2001). AFLP fingerprinting as a tool to study the genetic diversity of Rhizobium galegae isolated from Galega orientalis and Galega officinalis. J Biotechnol 91, 169-180.

Tighe, S. W., de Lajudie, P., Dipietro, K., Lindström, K., Nick, G. \& Jarvis, B. D. (2000). Analysis of cellular fatty acids and phenotypic relationships of Agrobacterium, Bradyrhizobium, Mesorhizobium, Rhizobium and Sinorhizobium species using the Sherlock Microbial Identification System. Int J Syst Evol Microbiol 50, 787-801.

van Berkum, P., Leibold, J. M. \& Eardly, B. D. (2006). Proposal for combining Bradyrhizobium spp. (Aeschynomene indica) with Blastobacter denitrificans and to transfer Blastobacter denitrificans (Hirsch and Muller, 1985) to the genus Bradyrhizobium as Bradyrhizobium denitrificans (comb. nov.). Syst Appl Microbiol 29, 207-215.

Vauterin, L. \& Vauterin, P. (1992). Computer-aided objective comparison of electrophoresis patterns for grouping and identification of microorganisms. Eur Microbiol 1, 37-41.

Versalovic, J., Schneider, M., De Bruijn, F. \& Lupski, J. (1994). Genomic fingerprinting of bacteria using repetitive sequence based PCR (rep-PCR). Methods Mol Cell Biol 5, 25-40.

Vincent, J. M. (1970). A Manual for the Practical Study of the Root Nodule Bacteria. Oxford: Blackwell Scientific.
Vinuesa, P., León-Barrios, M., Silva, C., Willems, A., Jarabo-Lorenzo, A., Pérez-Galdona, R., Werner, D. \& Martínez-Romero, E. (2005a). Bradyrhizobium canariense sp. nov., an acid-tolerant endosymbiont that nodulates endemic genistoid legumes (Papilionoideae: Genisteae) from the Canary Islands, along with Bradyrhizobium japonicum bv. genistearum, Bradyrhizobium genospecies alpha and Bradyrhizobium genospecies beta. Int J Syst Evol Microbiol 55, 569-575.

Vinuesa, P., Silva, C., Lorite, M. J., Izaguirre-Mayoral, M. L., Bedmar, E. J. \& Martínez-Romero, E. (2005b). Molecular systematics of rhizobia based on maximum likelihood and Bayesian phylogenies inferred from $r r s, a t p D, r e c A$ and nifH sequences, and their use in the classification of Sesbania microsymbionts from Venezuelan wetlands. Syst Appl Microbiol 28, 702-716.

Wang, J. Y., Zhang, Y. M., Wang, R., Liu, H. C., Wang, E. T., Sui, X. H. \& Chen, W. X. (2012). Bradyrhizobium daqingense sp. nov., a novel root nodule bacteria isolated from nodules of soybean grown in Daqing City of China. Int J Syst Evol Microbiol (in press) http://dx.doi.org/10. 1099/ijs.0.034280-0.

Wayne, L. G., Brenner, D. J., Colwell, R. R., Grimont, P. A. D., Kandler, O., Krichevsky, M. I., Moore, L. H., Moore, W. E. C., Murray, R. G. E. \& other authors (1987). International Committee on Systematic Bacteriology. Report of the ad hoc committee on reconciliation of approaches to bacterial systematics. Int J Syst Bacteriol 37, 463-464.

Weisburg, W. G., Barns, S. M., Pelletier, D. A. \& Lane, D. J. (1991). 16 S ribosomal DNA amplification for phylogenetic study. J Bacteriol 173, 697-703.

Willems, A. \& Collins, M. D. (1992). Evidence for a close genealogical relationship between Afipia (the causal organism of cat scratch disease), Bradyrhizobium japonicum and Blastobacter denitrificans. FEMS Microbiol Lett 96, 241-246.

Willems, A., Munive, A., de Lajudie, P. \& Gillis, M. (2003). In most Bradyrhizobium groups sequence comparison of 16S-23S rDNA internal transcribed spacer regions corroborates DNA-DNA hybridizations. Syst Appl Microbiol 26, 203-210.

Young, J. P. W. (1996). Phylogeny and taxonomy of rhizobia. Plant Soil 186, 45-52.

Zhang, Y. M., Li, Y. Jr, Chen, W. F., Wang, E. T., Tian, C. F., Li, Q. O., Zhang, Y. Z., Sui, X. H. \& Chen, W. X. (2011). Biodiversity and biogeography of rhizobia associated with soybean plants grown in the North China Plain. Appl Environ Microbiol 77, 6331-6342. 